\title{
Differences in Social Skills and Personal Responsibility between Students of High and Youth Schools
}

\section{Romualdas Malinauskas \\ Lithuanian Sports University, Faculty of Sports Education}

\section{Abstract}

The current study explored two constructs (social skills and personal responsibility) in the context of two different types of schools (high and youth schools), and strives to explain the differences in social skills and personal responsibility between students of high and youth schools. The sample comprised 408 students (203 males, 205 females). The mean age of the students was 16.72 years $(S D=0.96)$. Students completed measures of social skills (Riggio Social Skills Inventory) and personal responsibility (Personal Responsibility Scale (PRS)). Multivariate analysis of variance (MANOVA) was used to investigate how school type and gender affected social skills and dimensions of personal responsibility. Multivariate analysis showed the main effect of the school type and gender on social skills and personal responsibility in students. Univariate analysis indicated that students' social skills and personal responsibility were higher in high schools than in youth schools and in female than male students..

Key words: high school; personal responsibility; social skills; students; youth school.

\section{Introduction}

Researchers have studied students in high and youth schools in a number of ways and from different perspectives. Numerous studies (Findak, 2011; McKenney \& Dattilo, 2001) have demonstrated that appropriately structured and presented social education can contribute to the development of prosocial behaviour, and can reduce antisocial behaviour among the youth. As social skills and personal responsibility have a major impact on the personal life of an individual (Riggio, 1986), it is essential to explore what kind of ability and readiness to resist social oppression students in two 
different types of schools have. Some researchers focus only on the impact of social skills (Malinauskas \& Emeljanovas, 2013; Sniras \& Malinauskas, 2005) and some focus on personal responsibility among students (Linley \& Maltby, 2009; Mergler \& Patton, 2007).

The current study tries to explore two constructs (social skills and personal responsibility) in the context of two different types of schools (high and youth schools) and strives to answer the question what are the differences in social skills and personal responsibility between students in high and youth schools.

\section{Aspects of Social Skills}

Social skills are among the most important indicators of social competence, and they are like a connection between an individual and environment (Beauchamp \& Anderson, 2010; Malinauskas, Klizas, \& Bukauskas, 2014) because difficulties in social competence and peer relations lead to short-term, intermediate and long-term complications in educational, psychosocial and vocational domains of functioning (Gresham, 2016; Gumpel, 2007).

There are many definitions of the concept "social skills", but each definition complements the others (Malinauskas, Gudonis, \& Sniras, 2007). For instance, social skills can be conceptualised as a specific class of behaviours that an individual exhibits in order to successfully complete a social task (Gresham, 2016). Social tasks might include such things as peer group entry, having a conversation, making friends, or playing a game with peers. Given this conceptualisation, social skills are specific behaviours exhibited in specific situations that lead to judgements by others that these behaviours are competent or incompetent in accomplishing social tasks (Gresham, Elliott, \& Kettler, 2010; Gresham, 2016). In the present study a more comprehensive concept of social skills by Riggio (1986) is used. In regards with Riggio (1986), social skills are verbal and non-verbal communication skills including expressivity, sensitivity, and control. Expressivity refers to the skill with which one communicates or sends messages to others. Sensitivity refers to the skill with which one receives and interprets the communicated messages of others. Control refers to the skill with which one is able to regulate and manage the communication process. Social skills are important in a wide range of activities - academic, professional, peer interactions (Gresham, Elliott, Vance, \& Cook, 2011). Social skills may be viewed as observable and learned sets of self and interpersonal behaviours (e.g. cooperation) that lead to desired social outcomes (Riggio, Riggio, Salinas, \& Cole 2003). Students with higher social skills tend to perform better in school (Zsolnai \& Kasik 2014), have better quality relationships, resolve conflict in more constructive ways, and engage less frequently in unhealthy behaviours (Akelaitis, 2015; Gresham, 2016; Gumpel, 2007). Social skills also tend to enhance productivity and career success (Riggio et al., 2003). Because lack of social skills is usually caused by long-term and short-term difficulties in different areas - educational, psychological, professional (Gresham, 2016), it is very important 
to explore not only high school students' but also alternative (in our case - youth) school students' social skills.

\section{Aspects of Personal Responsibility}

The concept of personal responsibility has received increasing attention from researchers. Given the current social problems (e.g. school failure, drug addiction, alcoholism, etc.), it can be traced back to lack of personal responsibility (Smithkirai, Longthong, \& Peijsel, 2015). When adolescents take personal responsibility they consider their choices and their potential effect before acting, lessening the chance that they will act foolishly and hurt themselves and others (Mergler \& Patton, 2007). Definitions of personal responsibility have varied across time and research studies, making comparisons difficult. Mergler (2007, p. 66) defined personal responsibility as "the ability to regulate one's own thoughts, feelings and behaviour, along with a willingness to hold oneself accountable for the choices made and the social and personal outcomes generated". Lewis (2004) defined personal responsibility as the frequency with which students engaged in responsible classroom behaviours including protecting students' and teachers' rights associated with learning and emotional and physical safety. There were attempts to describe personal responsibility as an ability of an individual to take accountability for their decisions and actions, together with the outcomes they create and their impacts on others (Linley \& Maltby, 2009). The existing diversity of these concepts encourages the need for further investigation.

Recently, there has been agreement with Swaner's (2005) position, which argues that personal responsibility needs to be viewed as a multidimensional construct that includes behavioural, cognitive, emotional and moral components. In the present study the multidimensional concept of personal responsibility by Mergler and Shield (2016) is used because it encompasses three aspects of personal responsibility: personal accountability, behavioural and emotional control and cognitive control (Mergler \& Shield, 2016).

\section{Gender Differences in Social Skills and Personal Responsibility}

One of the reasons this study is needed is because the available data in the field of gender differences in social skills and personal responsibility are somewhat contradictory. Some studies have found that the teachers' and parents' ratings of social skills were higher for boys than for girls (Nourani, 1998) although other research on social skills and personal responsibility indicates that girls typically have higher social skills and personal responsibility than boys (Akelaitis, 2015; Christodoulides, Derri, Tsivitanidou, \& Kioumourtzoglou, 2012). These research results show the need for further investigation. It is not clear whether gender differences in social skills and personal responsibility are real developmental differences or they are just produced by the subjective perception of the raters (Zsolnai \& Kasik, 2014). Maybe schools and teachers provide educational climates that enhance the social behavioural advantage of girls (DiPrete \& Jennings, 2011). 
The second reason for deciding to investigate gender differences is based on earlier studies which reported that gender is among the most important considerations in social skills development (Abdi, 2010; DiPrete \& Jennings, 2011).

\section{Concept of Youth School}

Alternative schools or youth schools are described as schools mostly designed to serve students who had already dropped out of the regular school (Raywid, 1994). Youth schools are designed to provide specialized instruction to students who have discontinued their enrolment in conventional schools. Behavioural problems, truancy, poor academic performance, pregnancy, and court orders are only a few of the reasons determining student placement in youth school (Muñoz, 2004). The "youth school" is usually part of the middle or high school programme offered to students of secondary school age (Dunning-Lozano, 2016). The students attending these schools are typically underachieving and usually are deficient in credits to graduate or to be with their peers (Dunning-Lozano, 2016). The alternative schools or youth schools are those that generally cater for a special population, such as students with unique learning interests or disabilities, potential dropouts, violent individuals, or court-adjudicated youths and those in juvenile detention systems. Such schools are designed to return youths who have dropped out of high school to mainstream high schools, assist in credit recovery for youths who are behind in academic credits, or to facilitate the attainment of alternative educational credentials (Dunning-Lozano, 2016). Critical education scholars have criticized these youth schools as 'dumping grounds' or a 'separate track for a particular "under-class" of students', especially youths at risk, and as a mechanism to stratify students by socioeconomic status (Muñoz, 2004).

Topicality of investigation of personal responsibility and social skills in youth schools is based on the argument that very little is actually known about what goes on within the precincts of youth schools (Kelly, 1993). Some researchers (Muñoz, 2004; Wilhite \& Bullock, 2012) reported that alternative education, particularly that related to youth at risk, is often based on incomprehensive research. For this reason, the investigation of not only high schools but also of youth schools is the focus of the present study.

\section{This Study}

The aim of this study was to investigate social skills and personal responsibility in students of high and youth schools. This study makes a novel contribution to the literature, because other research in this field has only evaluated social skills in high schools students (Malinauskas \& Emeljanovas, 2013; Sniras \& Malinauskas, 2005), social skills in alternative (youth) schools students (Hovell, Blumberg, Liles, \& Powell, 2001; Wilhite \& Bullock, 2012), personal responsibility in high schools students (Wright, Li, Ding, \& Pickering, 2010), personal responsibility in alternative schools students (Pickering, 2008), whereas we investigated social skills and personal 
responsibility in students of both high and youth schools. This article brings together two areas of research that have individually received considerable attention, but that have not been analysed together: social skills and personal responsibility. We evaluated multiple aspects of personal responsibility (personal accountability, behavioural and emotional control, cognitive control) in order to provide comprehensive assessment of personal responsibility. We also analysed social skills and personal responsibility with respect to gender in the present study, because gender is among the important considerations in social skills development (Abdi, 2010; DiPrete \& Jennings, 2011; Ozben, 2013; Zsolnai \& Kasik 2014).

The following research questions guided the present study which is based on the integration of social skills and personal responsibility in the context of two different types of schools: 1) Do social skills and personal responsibility differ in students of high and youth schools? 2) Are there gender differences in social skills and personal responsibility levels in students of high and youth schools?

We investigated two hypotheses based on previous research:

(H1) High school students' social skills and personal responsibility are significantly higher than those of youth school students. This hypothesis was based on earlier research (Cash, 2004) showing that youth school students exhibited lower social skills and personal responsibility because youth schools are designed to provide specialized instruction to students that have behavioural problems, truancy and poor academic performance.

(H2) Female students' social skills and personal responsibility are significantly higher than those of male students. This hypothesis was based on an earlier study which reported that females acquire social skills earlier in life than males do and because they have better prosocial skills (Bennett, Farrington, \& Huesmann, 2005). The hypothesis was based on the finding by Margetts (2005), indicating that girls have better social skills than their male peers because secondary school age boys more frequently face a range of behavioural problems and use physical violence more frequently.

\section{Methods \\ Participants}

The sample of students was randomly selected. For the purpose of this study, four hundred and twenty participants were recruited from different high and youth schools in Kaunas region. Participants were not offered any incentive to participate. Students who provided incomplete data were excluded from the analyses, yielding a final sample of 408. Participants comprised 203 male and 205 female students; 210 of them were high school students, and 198 of them were youth school students. The mean age of the students was 16.72 years $(S D=0.96)$. There were no gender differences in age between students of high and youth schools $(\mathrm{t}(406)=-1.53$, ns). Participants completed the questionnaire during scheduled class time, with no time limit. The 
researcher introduced the study and gave the participants information about the study aims prior to administering the questionnaire, which was presented in Lithuania. The study was approved by the Committee for Social Sciences Research Ethics of Lithuanian Sport University. The research was conducted in accordance with ethical guidelines and the legal code of the country in which the study was conducted. The questionnaire contained the instruments listed below.

\section{Instruments}

Social Skills Inventory (SSI). The SSI, developed by Riggio (1986), is a 90-item Likert-type self-report inventory which consists of six subscales, each with 15 items evaluated according to a 5 -point scale $(1=$ not at all like me, $5=$ exactly like $m e$ ). It is used to calculate an individual's level of global social skills. Higher scores indicate a higher level of social skills. Riggio (1986) gained a test-retest reliability coefficient of .94 and a concurrent validity and discriminant validity range of .12 to .47 . The alpha coefficient for the total scale was .67 for the present sample. The Lithuanian version of the SSI shows internal consistency value .82 and a test-retest reliability coefficient of .86 for the overall questionnaire (Malinauskas, 2004).

Personal Responsibility Scale (PRS; Mergler \& Shield, 2016). The PRS comprised 15 items that measure aspects of personal responsibility and utilised a Likert scale with 1 meaning strongly disagree and 4 meaning strongly agree. Thus, total score ranges from 15 to 60, while high scores indicate high personal responsibility. The PRS consists of a series of items reflecting three aspects of personal responsibility: personal accountability (a willingness of an individual to hold oneself accountable for one's choices); behavioural and emotional control (encompasses diverse behaviours that reflect an individual's ability (or lack of it) to regulate impulses in socially adaptive ways) and cognitive control (the ability to regulate one's own thoughts) (Mergler \& Shield, 2016). Participants were asked to circle the response that appeared true of them most of the time. Examples of items include, 'I often lash out when I am all stirred up', and 'I choose how to respond in situations'. Reliability was checked using Cronbach's alpha. For the three subscales, Cronbach's alpha had been .81, .81, and .71, and was considered adequate (George \& Mallery, 2014). In the current study, a Cronbach's alpha of .65 was found for the PRS total score, indicating acceptable internal reliability. Cronbach's alphas for the subscales were .69, .67, and .61, and were also considered as adequate (George \& Mallery, 2014).

Personal Information Form. Participants were asked to record their sociodemographic variables such as gender, age, and school type.

\section{Data Analysis}

Descriptive statistics, namely means, standard deviations and mean differences (Ds), were calculated. Skewness (the symmetry of a distribution) and kurtosis (the 
homogeneity of a distribution) coefficients were calculated to assess univariate normality because MANOVA requires normally distributed data (Gravetter \& Wallnau, 2000). As a rule of thumb, skewness and kurtosis coefficients between +1 and -1 are considered to indicate that data are normally distributed (Garson, 2012). Two-tailed Pearson product moment correlations are reported for all continuous variables.

MANOVA was used to investigate the effects of school type and gender on social skills and dimensions of personal responsibility. Preliminary tests were conducted to check for multicollinearity, sphericity and homogeneity of variance. The results indicated that there were no serious violations of the MANOVA assumptions. Wilks' lambda was used to evaluate all multivariate effects, and the significance level was set at .05. Effect sizes for $F$-statistics were expressed as partial eta-squared $\left(\eta_{p}{ }^{2}\right)$. This statistical data ranges from 0 to 1 and represents the proportion of variance in the dependent variable which is explained by the independent (group) variable. According to Tabachnick and Fidell (2007), effect size based on $\eta_{\mathrm{p}}{ }^{2}=.01$ corresponds to a small effect, $\eta_{\mathrm{p}}{ }^{2}=.09$ corresponds to a medium effect, and $\eta_{\mathrm{p}}^{2}=.25$ represents a large effect. All statistical analyses were conducted using SPSS (version 24.0).

\section{Results}

This study attempted to determine differences in social skills and personal responsibility between students of high and youth schools. The findings obtained in the study are provided below. Table 1 presents the means, standard deviations, skewness and kurtosis, and standard errors of skewness and kurtosis for all variables. All variables were checked for skewness and kurtosis and were considered to have acceptable distributions, thus making it possible to use MANOVA.

Table 1

Means $(M)$, standard deviations (SD), and normality tests of the study variables

\begin{tabular}{|c|c|c|c|c|c|c|c|c|c|c|c|c|}
\hline & \multicolumn{6}{|c|}{ High schools $(N=210)$} & \multicolumn{6}{|c|}{ Youth schools $(\mathrm{N}=198)$} \\
\hline & $M$ & $S D$ & Sk & SkSE & $\mathrm{Ku}$ & KuSE & $M$ & $S D$ & Sk & SkSE & $\mathrm{Ku}$ & KUSE \\
\hline Social skills & 278.4 & 20.94 & .77 & .17 & 1.91 & .33 & 273.69 & 17.97 & -.03 & .17 & -.35 & .34 \\
\hline Personal accountability & 17.61 & 2.29 & -.05 & .17 & -.69 & .33 & 17.25 & 2.27 & .02 & .17 & .13 & .34 \\
\hline $\begin{array}{l}\text { Behavioural and } \\
\text { emotional control }\end{array}$ & 14.68 & 2.16 & -.23 & .17 & -.46 & .33 & 14.13 & 2.10 & -.14 & .17 & -.12 & .34 \\
\hline Cognitive control & 11.719 & 1.85 & -.04 & .17 & -.30 & .33 & 11.61 & 1.94 & -.37 & .17 & -.10 & .34 \\
\hline Total PR score & 44.02 & 3.78 & -.04 & .17 & -.22 & .33 & 42.98 & 3.90 & -.19 & .17 & -.05 & .34 \\
\hline
\end{tabular}

Notes. PR - Personal responsibility, Sk - Skewness, SkSE - Skewness standard error, Ku - Kurtosis, KuSE - Kurtosis standard error.

Pearson correlation coefficients were calculated to investigate the pattern of correlations between dependent variables and confirm the absence of multicollinearity. MANOVA is considered wasteful if dependent variables are very highly positively correlated or uncorrelated (Tabachnick \& Fidell, 2007). Correlations between 
dependent variables are presented separately for high and youth schools students in Table 2. The dependent variables were correlated in the positive direction.

Table 2

Correlations of dependent variables

\begin{tabular}{lccccc}
\hline & 1 & 2 & 3 & 4 & 5 \\
\hline 1. Social skills & 1 & $.42^{* *}$ & $.46^{* *}$ & $.50^{* *}$ & $.76^{* *}$ \\
2. Personal accountability & $.34^{* *}$ & 1 & .07 & .09 & $.59^{* *}$ \\
3. Behavioural and emotional control & $.55^{* *}$ & $.16^{*}$ & 1 & $.16^{*}$ & $.61^{* *}$ \\
4. Cognitive control & $.42^{* *}$ & .08 & .06 & 1 & $.60^{* *}$ \\
5. Total personal responsibility score & $.71^{* *}$ & $.66^{* *}$ & $.66^{* *}$ & $.52^{* *}$ & 1 \\
\hline
\end{tabular}

Notes. Correlations below the diagonal are for youth schools. $N=198$. Correlations above the diagonal are for high schools. $N=210 .{ }^{*} p<.05 ;{ }^{* *} p<.01$.

Homogeneity of variances was assessed with Levene's test and found to be satisfactory (all $p>.05)$.

MANOVA was used to investigate how school type and gender affected social skills and dimensions of personal responsibility. Multivariate analyses of MANOVA revealed a small main effect for school type $(F(4,401)=2.73, p=.029$; Wilk's $\lambda=0.97$; $\left.\eta_{\mathrm{p}}{ }^{2}=.03\right)$. A multivariate test indicated that gender also affects social skills and dimensions of personal responsibility $(F(4,401)=2.77, p=.027$, Wilk's $\lambda=.97$; $\left.\eta_{\mathrm{p}}{ }^{2}=.03\right)$. Overall MANOVA results did not show a significant effect for school type by gender interaction $(F(4,401)=1.76, p=.136$; Wilk's $\lambda=.98)$.

Univariate analyses of MANOVA confirmed effects of school type on three dependent variables (Table 3).

Table 3

Means (M) and standard deviations (SD) for personal responsibility dimensions and social skills

\begin{tabular}{|c|c|c|c|c|c|c|c|c|c|c|c|c|c|c|}
\hline & \multicolumn{4}{|c|}{ High schools $(N=210)$} & \multicolumn{4}{|c|}{ Youth schools $(N=198)$} & \multicolumn{6}{|c|}{ Univariate tests of MANOVA } \\
\hline & \multicolumn{2}{|c|}{ Males } & \multicolumn{2}{|c|}{ Females } & \multicolumn{2}{|c|}{ Males } & \multicolumn{2}{|c|}{ Females } & \multirow{2}{*}{$\begin{array}{c}\text { School } \\
\text { type }(S T) \\
F(d f=1,404)\end{array}$} & \multicolumn{3}{|c|}{ Gender } & \multirow{2}{*}{$\begin{array}{c}\text { ST } x \\
\text { Gender } \\
F \\
(d f=1,404)\end{array}$} & \multirow[b]{2}{*}{$\eta_{p}^{2}$} \\
\hline & M & SD & M & SD & M & SD & M & SD & & $\eta_{p}^{2}$ & $\begin{array}{c}F \\
(d f=1,404)\end{array}$ & $\eta_{p}^{2}$ & & \\
\hline Social skills & 275.42 & 18.03 & 281.71 & 23.35 & 271.79 & 18.68 & 275.42 & 17.22 & $6.63^{*}$ & 0.02 & $6.63^{*}$ & 0.02 & 0.47 & 0.00 \\
\hline $\begin{array}{l}\text { Personal } \\
\text { accountability }\end{array}$ & 17.51 & 2.40 & 17.72 & 2.16 & 16.87 & 2.30 & 17.59 & 2.21 & 2.95 & 0.01 & $4.25^{*}$ & 0.01 & 1.29 & 0.00 \\
\hline BEC & 14.57 & 2.07 & 14.81 & 2.25 & 13.74 & 1.92 & 14.48 & 2.20 & $7.74^{* *}$ & 0.02 & $5.39 *$ & 0.01 & 1.38 & 0.00 \\
\hline $\begin{array}{l}\text { Cognitive } \\
\text { control }\end{array}$ & 11.51 & 1.91 & 11.95 & 1.76 & 11.53 & 1.98 & 11.67 & 1.91 & 0.46 & 0.00 & 2.45 & 0.00 & 0.64 & 0.00 \\
\hline Total PR score & 43.59 & 3.74 & 44.48 & 3.80 & 42.14 & 3.93 & 43.74 & 3.73 & $8.50 * *$ & 0.02 & $10.93 * *$ & 0.03 & 0.87 & 0.00 \\
\hline
\end{tabular}

Notes. ${ }^{*} p<0.05 .{ }^{* *} p<0.01$. BEC - Behavioural and emotional control, PR - Personal responsibility.

Simple main effects analysis showed that students of high schools reported higher social skills $(D=4.75, p=.010)$, behavioural and emotional control $(D=$ $.56, p=.006)$ and total personal responsibility score $(D=1.04, p=.004)$. Follow-up 
univariate analysis revealed a small effect $\left(\eta_{\mathrm{p}}{ }^{2}=.02\right)$ of gender on social skills score $(D=4.78, p=.010)$ : females had a higher level in social skills. Univariate analyses for gender also revealed effects on these dependent variables: personal accountability $\left(F(1,404)=4.25 ; p=.040, \eta_{\mathrm{p}}{ }^{2}=.01\right)$, behavioural and emotional control $(F(1,404)$ $\left.=5.39 ; \mathrm{p}=.021, \eta_{\mathrm{p}}^{2}=.01\right)$, and total personal responsibility score $(F(1,404)=10.93$; $\left.p=.001, \eta_{\mathrm{p}}{ }^{2}=.03\right)$. Personal accountability and behavioural and emotional control were higher in females than in males.

\section{Discussion}

The aim of this study was to examine social skills and personal responsibility in students of high and youth schools. In the present study, students' social skills and personal responsibility were studied for their differences as well as for the differences between male and female students. We did not find a significant effect for school type by gender interaction on social skills and personal responsibility, but the study revealed differences in social skills and personal responsibility between high and youth school students, as well as between male and female students. A multivariate test indicated that school type and gender affect social skills and personal responsibility (a small main effect $\eta_{\mathrm{p}}^{2}=.03$ in both cases).

Our first hypothesis that high school students' social skills and personal responsibility are significantly higher than those of youth school students was confirmed. The current study has shown that high schools students' social skills were higher than those of youth school students (effect size was weak, $\eta_{\mathrm{p}}{ }^{2}=.02$ ), which is in line with the data obtained by Malinauskas et al. (2014), where high schools students had higher level of social skills: acceptance of others, emotional comfort and internality among students of high schools was higher than among students of youth schools (effect size was weak and varied from Cohen's $d=-.18$ to Cohen's $d=-.24$ ). Youth school students' lower social skills can be explained by the students' personal characteristics because youth schools are designed to provide specialized instruction to students that have behavioural problems, truancy and poor academic performance. In addition, the enhancement of social skills can be highly influenced by teaching/ learning conditions, during which students have the opportunity to communicate and cooperate. Some studies (for instance, Cash, 2004) indicated that alternative/youth schools have been successful in reducing truancy, improving attitudes toward school and reducing behaviour problems.

The present study has also shown that high schools students' personal responsibility and behavioural and emotional control (the aspect of personal responsibility) were higher than those of youth school students. The effect sizes for the observed differences were small $\left(\eta_{\mathrm{p}}{ }^{2}=.02\right)$. Our findings on the observed differences support Aron's and Zweig's (2003) claim that youth school students have no behavioural control. The results of this study are in line with another study which found that youth school students have higher levels of disruptive verbal behaviour (Kleiner, 
Porch, \& Farris, 2002). The results are also consistent with a study showing that low behavioural and emotional control, lack of anger management, and substance abuse are important factors associated with in-school behaviour, which reflect learners' low ability to engage responsibly in self-regulation while attending alternative/youth school settings (Herndon \& Bembenutty, 2014). The fact that youth school students exhibited lower levels of behavioural and emotional control is in line with the concept of personal responsibility by Mergler and Shield (2016), who showed the importance of behavioural and emotional control as a dimension of personal responsibility.

Our results support Hypothesis 2, that the female students' social skills and personal responsibility are significantly higher than those of male students (effect size was small, $\left.\eta_{\mathrm{p}}{ }^{2}=.03\right)$. Univariate analysis revealed a small effect $\left(\eta_{\mathrm{p}}{ }^{2}=.02\right)$ of gender on students' social skills. This result is very similar to previous research results (Margalit \& Eysenck, 1990; Zsolnai \& Kasik, 2014), where girls showed a higher level of social skills than boys; effect size was small $\left(\eta_{p}{ }^{2}=.03\right)$. These findings of the present study could be explained by the findings of Bennett et al. (2005), showing that females acquire social skills earlier in life than males do and because they have better prosocial skills. Boys develop self-control ability later than girls, so they often cannot control their emotions, they quickly become angry, lack respect and tolerance for other people, often do not understand their own and other people's feelings (Bennett et al., 2005). The superior social skills of females could be also influenced by many factors, including greater verbal ability and differential socialization by parents and peers (Bennett et al., 2005; Ozben, 2013).

Univariate analysis indicated that gender affects personal responsibility, and revealed a small effect of gender on total personal responsibility score $\left(\eta_{\mathrm{p}}{ }^{2}=.03\right)$ and on aspects of personal responsibility: personal accountability $\left(\eta_{\mathrm{p}}^{2}=.01\right)$ and behavioural and emotional control $\left(\eta_{\mathrm{p}}{ }^{2}=.01\right)$. This result with respect to gender is in line with those gained by researchers such as Carbonero, Martín-Antón, Monsalvo, and Valdivieso (2015), where low effect size has been established for one of the aspects of personal and social responsibility (Cohen's $d=.26$ ). A possible explanation of higher levels of females' personal responsibility could be that schools of both types (high schools and youth schools) could provide educational climates that enhance personal responsibility and the social behavioural advantage of females (DiPrete \& Jennings, 2011). For instance, Entwisle, Alexander, and Olson (2007) argued that girls have better social and behavioural ratings not so much because of differences in maturity but rather because "they find the student role more compatible than boys do" (p. 134), i.e. they have higher levels of personal accountability and behavioural and emotional control.

\section{Limitations and Future Research}

The strength of this study is a relatively large sample. However, it has some limitations. The present study is a cross-sectional rather than experimental study, 
and the correlational nature of the study design makes it difficult to draw cause-andeffect conclusions, i.e., that school type and gender cause social skills and personal responsibility. The second limitation of the present research is that we relied on a single measure of social skills. Although the SSI is the most commonly used measure of social skills, there are other measures that might have provided a more nuanced assessment (for instance, School Social Behaviour Scale, which is used to assess social skills and antisocial behaviour across environment). The variables of interest in this study were restricted to gender, school type, social skills, and personal responsibility. Future researchers could expand our research design to examine different psychosocial variables, such as self-esteem, self-efficacy and well-being.

\section{Conclusion}

Multivariate analysis showed the main effect of the school type and gender on social skills and personal responsibility in students. Univariate analysis indicated that students' social skills and personal responsibility were higher in high schools than in youth schools and in female than in male students.

\section{References}

Abdi, B. (2010). Gender differences in social skills, problem behaviours and academic competence of Iranian preschool children based on their parent and teacher ratings. Procedia-Social and Behavioral Sciences, 5, 1175-1179. https://doi.org/10.1016/j. sbspro.2010.07.256

Akelaitis, A. V. (2015). Social Skills Expression of Senior High School Age Students in Physical Education Classes. European Journal of Contemporary Education, 14(4), 232-238. https://doi.org/10.13187/ejced.2015.14.232

Aron, L.Y., \& Zweig, J. M. (2003). Educational alternatives for vulnerable youth: Student needs, program types, and research directions. Washington, DC: Urban Institute. https://doi. org/10.1037/e723262011-001

Beauchamp, M. H., \& Anderson, V. (2010). SOCIAL: an integrative framework for the development of social skills. Psychological Bulletin, 136(1),39-64. https://doi.org/10.1037/ $\underline{\mathrm{a} 0017768}$

Bennett, S., Farrington, D. P., \& Huesmann, L. R. (2005). Explaining gender differences in crime and violence: The importance of social cognitive skills. Aggression and Violent Behavior, 10(3), 263-288. https://doi.org/10.1016/j.avb.2004.07.001

Cash, T. (2004). Alternative schooling. In J. Smink, \& F. P. Schargel (Eds.), Helping Students Graduate: A Strategic Approach to Dropout Prevention (pp. 165-174). Larchmont, NY: Eye on Education. https://doi.org/10.4324/9781315854816-12 
Carbonero, M. A., Martín-Antón, L. J., Monsalvo, E., \& Valdivieso, J. A. (2015). School performance and personal attitudes and social responsibility in preadolescent students. Anales de Psicología/Annals of Psychology, 31(3), 990-999. https://doi.org/10.6018/ analesps.31.3.181161

Christodoulides, E., Derri, V., Tsivitanidou, O., \& Kioumourtzoglou, E. (2012). Differences in social skills of Cypriot students in the physical education class. Journal of Physical Education and Sport, 12(3), 371-380.

DiPrete, T. A., \& Jennings, J. L. (2011). Social and behavioral skills and the gender gap in early educational achievement. Social Science Research, 41(1), 1-15. https://doi.org/10.1016/j. ssresearch.2011.09.001

Dunning-Lozano, J. L. (2016). Race and opportunity in a public alternative school. Race Ethnicity and Education, 19(2), 433-460. https://doi.org/10.1080/13613324.2014.911163

Entwisle, D. R., Alexander, K. L., \& Olson, L. S. (2007). Early Schooling: The handicap of being poor and male. Sociology of Education, 80(2), 114-138. https://doi. org/10.1177/003804070708000202

Findak, V. (2011). Kinesiological prevention in the field of education. Croatian Journal of Education, 13(4), 71-86.

Garson, G. D. (2012). Testing statistical assumptions. Blue book series. North Carolina: Statistical Associates Publishing.

George, D., \& Mallery, P. (2014). IBM SPSS statistics 21 step by step: A simple guide and reference (13th ed.). London, UK: Pearson.

Gresham, F. M. (2016). Social skills assessment and intervention for children and youth. Cambridge Journal of Education, 46(3), 319-332. https://doi.org/10.1080/030576 $\underline{4 X .2016 .1195788}$

Gresham, F. M., Elliott, S. N., \& Kettler, R. J. (2010). Base rates of social skills acquisition/ performance deficits, strengths and problem behaviors: An analysis of the social skills improvement system - rating scales. Psychological Assessment, 22(4), 809-815. https://doi. org/10.1037/a0020255

Gresham, F. M., Elliott, S. N., Vance, M. J., \& Cook, C. R. (2011). Comparability of the social skills rating system to the social skills improvement system: Content and psychometric comparisons across elementary and secondary age levels. School Psychology Quarterly, 26 (1), 27-44. https://doi.org/10.1037/a0022662

Gumpel, T. P. (2007). Are social competence difficulties caused by performance or acquisition deficits? The importance of self-regulatory mechanisms. Psychology in the Schools, 44, 351372. https://doi.org/10.1002/pits.20229

Herndon, J. S., \& Bembenutty, H. (2014). In-school and social factors influencing learning among students enrolled in a disciplinary alternative school. Learning and Individual Differences, 35, 49-55. https://doi.org/10.1016/j.lindif.2014.07.007

Hovell, M. F., Blumberg, E. J., Liles, S., \& Powell, L. (2001). Training AIDS and anger prevention social skills in at-risk adolescents. Journal of Counseling and Development: JCD, 79(3), 347-355. https://doi.org/10.1002/j.1556-6676.2001.tb01980.x

Kelly, D. M. (1993). Last chance high. New Haven, Conn.: Yale University Press. 
Kleiner, B., Porch, R., \& Farris, E. (2002). Public Alternative Schools and Programs for Students at Risk of Education Failure: 2000-01 (NCES 2002-004). US Department of Education. Washington, DC: National Center for Education Statistics. https://doi.org/10.1037/ e492172006-007

Lewis, R. (2004). Kids behaving badly, or responsibly? Helping teachers help students to act responsibly. Professional Educator, 3(4), 17-19.

Linley, P. A., \& Maltby, J. (2009). Personal responsibility. In S. J. Lopez (Ed.), The Encyclopedia of Positive psychology (pp. 685-689). Boston, MA: Blackwell Publishing.

Malinauskas, R. (2004). Assessment to basic social skills (based on the data of the research of sport pedagogues). Ugdymo Psichologija [Educational Psychology], 11, 197-201.

Malinauskas, R., Dumciene, A., \& Lapeniene, D. (2014). Social skills and life satisfaction of Lithuanian first-and senior-year university students. Social Behavior and Personality: An International Journal, 42(2), 285-293. https://doi.org/10.2224/sbp.2014.42.2.285

Malinauskas, R., \& Emeljanovas, A. (2013). Specificity of schoolchildren's social skills during physical education classes. Croatian Journal of Education, 15, 51-68.

Malinauskas, R., Gudonis, V., \& Sniras, S. (2007). Dynamics of social-psychological competence among pedagogical university students. Psichologiceskij Zurnal [Psychological Journal], 28(4), 45-51.

Malinauskas, R., Klizas, S., \& Bukauskas, G. (2014). Peculiarities of the Psychosocial Adjustment Among Students of Youth and Secondary Schools. European Journal of Physical Education and Sport, 5(3), 185-191. https://doi.org/10.13187/ejpe.2014.5.185

Margalit, M., \& Eysenck, S. (1990). Prediction of coherence in adolescence: Gender differences in social skills, personality, and family climate. Journal of Research in Personality, 24(4), 510-521. https://doi.org/10.1016/0092-6566(90)90036-6

Margetts, K. (2005). Children's adjustment to the first year of schooling: indicators of hyperactivity, internalising and externalising behaviours. International Journal of Transitions in Childhood, 1, 36-44.

McKenney, A., \& Dattilo, J. (2001). Effects of an intervention within a sport context on the pro-social and antisocial behavior of adolescents with disruptive behavior disorders. Therapeutic Recreation Journal, 35, 123-140.

Mergler, A. G. (2007). Personal responsibility: the creation, implementation and evaluation of a school-based program: PhD thesis. Brisbane: Queensland University of Technology.

Mergler, A., \& Patton, W. (2007). Adolescents talking about personal responsibility. The Journal of Student Wellbeing, 1(1), 57-70. https://doi.org/10.21913/JSW.v1i1.113

Mergler, A., \& Shield, P. (2016). Development of the Personal Responsibility Scale for adolescents. Journal of Adolescence, 51, 50-57. https://doi.org/10.1016/j. adolescence.2016.05.011

Muñoz, J. S. (2004). The social construction of alternative education: Re-examining the margins of public education for at-risk Chicano/a students. The High School Journal, 88(2), 3-22. https://doi.org/10.1353/hsj.2004.0025

Nourani, K. (1998). Social skills and adaptive behavior of Iranian preschoolers: teachers' and parents' ratings (Doctoral dissertation). Toronto University of Toronto. 
Ozben, S. (2013). Social skills, life satisfaction, and loneliness in Turkish university students. Social Behavior and Personality, 41(2), 203-214. https://doi.org/10.2224/sbp.2013.41.2.203

Pickering, M. (2008). Measuring students' perceptions of personal and social responsibility and the relationship to intrinsic motivation in urban physical education. Journal of Teaching in Physical Education, 27, 167-178. https://doi.org/10.1123/jtpe.27.2.167

Raywid, M. (1994). Alternative schools: The state of the art. Educational Leadership, 52(1), 26-31.

Riggio, R. E. (1986). Assessment of basic social skills. Journal of Personality and Social Psychology, 51(3), 649-660. https://doi.org/10.1037/0022-3514.51.3.649

Riggio, R. E., Riggio, H. R., Salinas Ch., \& Cole, E. J. (2003). The role of social and emotional communication skills in leader emergence and effectiveness. Group Dynamics: Theory, Research, and Practice, 7(2), 83-103. https://doi.org/10.1037/1089-2699.7.2.83

Smithkirai, C., Longthong, N., \& Peijsel, C. (2015). Effect of using movies to enhance personal responsibility of university students. Asian Social Science, 11(5), 1-9. https://doi. org/10.5539/ass.v11n5p1

Sniras, S., \& Malinauskas, R. (2005). Moral skills of schoolchildren. Social Behavior and Personality: An International Journal, 33(4), 383-390. https://doi.org/10.2224/ $\underline{\text { sbp.2005.33.4.383 }}$

Swaner, L. E. (2005). Educating for personal and social responsibility: A review of the literature. Liberal Education, 91(3), 14-21.

Tabachnick, T. B., \& Fidell, L. (2007). Using multivariate statistics (5th ed.). Boston, MA: Allyn \& Bacon.

Wilhite, S., \& Bullock, L. M. (2012). Effects of the WhyTry social skills program on students with emotional and/or behavioral problems in an alternative school. Emotional and Behavioural Difficulties, 17(2), 175-194. https://doi.org/10.1080/13632752.2012.675135

Wright, P. M., Li, W., Ding, S., \& Pickering, M. (2010). Integrating a personal and social responsibility program into a Wellness course for urban high school students: assessing implementation and educational outcomes. Sport, education and society, 15(3), 277-298. https://doi.org/10.1080/13573322.2010.493309

Zsolnai, A., \& Kasik, L. (2014). Functioning of Social Skills from Middle Childhood to Early Adolescence in Hungary. International Journal of Emotional Education, 6(2), 54-68.

\author{
Romualdas Malinauskas \\ Department of Health, Physical and Social Education, \\ Faculty of Sports Education \\ Lithuanian Sports University \\ Sporto 6, 44221 Kaunas, Lithuania \\ romualdas.malinauskas@lsu.It
}




\section{Razlike u socijalnim vještinama i osobnoj odgovornosti između učenika srednjih škola i učenika škola za mladež}

\section{Sažetak}

U ovome istraživanju ispitana su dva konstrukta (socijalne vještine i osobna odgovornost) u kontekstu dviju različitih vrsta škola (srednje škole i škole za mladež) i pokušalo se odgovoriti na pitanje koje razlike postoje izmedu učenika srednjih škola $i$ škola za mladež s obzirom na socijalne vještine i osobnu odgovornost. Uzorak se sastojao od 408 učenika (203 muškog i 205 ženskog spola). Prosječna srednja dob učenika bila je 16,72 godine (SD =0,96). Učenici su ispunili upitnike o socijalnim vještinama (Riggijev Inventar socijalnih vještina) i osobnoj odgovornosti (Skala osobne odgovornosti). Koristila se multivarijatna analiza varijance (MANOVA) kako bi se ispitalo kako vrsta srednje škole i spol utječu na socijalne vještine i dimenzije osobne odgovornosti. Mutivarijatna analiza pokazala je glavni utjecaj vrste škole i spola na socijalne vještine $i$ osobnu odgovornost kod učenika. Univarijatna analiza pokazala je da su socijalne vještine i osobna odgovornost veći kod učenika u srednjim školama nego kod učenika u školama za mladež, kao i da su veći kod žena nego kod muškaraca.

Ključne riječi: osobna odgovornost; socijalne vještine; srednja škola; škola za mladež; učenici.

\section{Uvod}

Istraživači proučavaju učenike srednjih škola i škola za mladež na različite načine i iz različitih perspektiva. Brojna istraživanja (Findak, 2011; McKenney i Dattilo, 2001) pokazuju da dobro strukturirana i prezentirana socijalna komponenta obrazovanja može doprinijeti razvoju prosocijalnoga ponašanja te da može smanjiti antisocijalno ponašanje mladih osoba. Kako socijalne vještine i osobna odgovornost imaju velik utjecaj na osobni život pojedinca (Riggio, 1986), od velike je važnosti istražiti koliko su spremni i kakve sposobnosti imaju učenici tih dviju različitih vrsta škola kako bi odoljeli društvenom pritisku. Neki istraživači usredotočili su se samo na utjecaj socijalnih vještina (Malinauskas i Emeljanovas, 2013; Sniras i Malinauskas, 2005), 
a neki su usmjereni samo na osobnu odgovornost učenika (Linley i Maltby, 2009; Mergler i Patton, 2007).

Ovim istraživanjem pokušavaju se istražiti dva konstrukta (socijalne vještine i osobna odgovornost) u kontekstu dviju različitih vrsta škola (srednje škole i škole za mladež) i pokušava se naći odgovor na pitanje koje razlike postoje u socijalnim vještinama i osobnoj odgovornosti između učenika srednjih škola i škola za mladež.

\section{Aspekti socijalnih vještina}

Socijalne vještine među najvažnijim su pokazateljima socijalne kompetencije, a ujedno su i svojevrsna veza između pojedinca i okoline (Beauchamp i Anderson, 2010; Malinauskas, Klizas i Bukauskas, 2014) jer poteškoće u socijalnoj kompetenciji i odnosima među vršnjacima vode kratkoročnim, izravnim i dugoročnim komplikacijama u obrazovnom, psihosocijalnom i strukovnom području života (Gresham, 2016; Gumpel, 2007).

Postoje mnoge definicije pojma „socijalne vještine“, ali sve se one međusobno nadopunjavaju (Malinauskas, Gudonis i Sniras, 2007). Na primjer, socijalne vještine mogu se zamisliti kao određena skupina ponašanja koje pojedinac pokazuje kako bi uspješno obavio nekakvu društvenu aktivnost (Gresham, 2016). Te društvene aktivnosti mogu se odnositi na ulazak u skupinu vršnjaka, vođenje razgovora s njima, stvaranje prijateljstava ili igranje igara $s$ vršnjacima. $S$ obzirom na takvo poimanje socijalnih vještina, one su specifična ponašanja koja se iskazuju u određenim situacijama u kojima druge osobe mogu procijeniti jesu li takva ponašanja odgovarajuća ili neodgovarajuća za izvršavanje društvenih aktivnosti (Gresham, Elliott, i Kettler, 2010; Gresham, 2016). U ovome istraživanju koristio se sveobuhvatniji pojam socijalnih vještina, prema Riggiovu modelu (1986). Prema Riggiju (1986), socijalne vještinu su verbalne i neverbalne komunikacijske vještine koje obuhvaćaju izražajnost, osjetljivost i kontrolu. Izražajnost se odnosi na vještinu komuniciranja s drugim ljudima ili slanja poruka drugim ljudima. Osjetljivost se odnosi na vještinu primanja i interpretiranja poruka koje šalju drugi ljudi. Kontrola se odnosi na vještinu s pomoću koje pojedinac regulira i upravlja komunikacijskim procesom. Socijalne vještine važne su u velikom broju aktivnosti - akademskih, profesionalni, kao i interakcijama s vršnjacima (Gresham, Elliott, Vance i Cook, 2011). Socijalne vještine mogu se promatrati kao uočljiv i naučen skup vlastitih ponašanja i ponašanja u interakciji s drugim ljudima (npr. suradnji) koji vode željenim društvenim ishodima (Riggio, Riggio, Salinas i Cole 2003). Učenici s bolje razvijenim socijalnim vještinama obično imaju bolji uspjeh u školi (Zsolnai i Kasik 2014), imaju kvalitetnije odnose s drugim ljudima, rješavaju konfliktne situacije na konstruktivniji način te se rijetko upuštaju u nezdrave oblike ponašanja (Akelaitis, 2015; Gresham, 2016; Gumpel, 2007). Socijalne vještine također poboljšavaju produktivnost i uspjeh u karijeri (Riggio i sur., 2003). Zbog toga što je pomanjkanje socijalnih vještina često uzrokovano dugoročnim i kratkoročnim poteškoćama u različitim područjima - obrazovanju, psihološkom i profesionalnom 
području (Gresham, 2016), jako je važno istražiti ne samo socijalne vještine učenika srednjih škola nego i socijalne vještine učenika alternativnih škola (u našem slučaju škola za mladež).

\section{Aspekti osobne odgovornosti}

Pojam osobne odgovornosti privlači sve veću pažnju istraživača. Zbog aktualnih društvenih problema (kao što su školski neuspjeh, ovisnost o drogama, alkoholizam itd.) taj se pojam može proučavati i putem nedostatka osobne odgovornosti (Smithkirai, Longthong, i Peijsel, 2015). Kada adolescenti preuzmu osobnu odgovornost, razmatraju svoj izbor i njegov potencijalni učinak prije nego postupe na neki način, što umanjuje mogućnost da će se nerazborito ponašati i povrijediti sebe i druge (Mergler i Patton, 2007). Definicije osobne odgovornosti variraju tijekom vremena i u različitim istraživanjima, što otežava njihovu usporedbu. Mergler (2007, str. 66) je definirao osobnu odgovornost kao „sposobnost reguliranja vlastitih misli, osjećaja i ponašanja, uz spremnost na preuzimanje odgovornosti za vlastiti izbor i za socijalne i osobne posljedice koje pri tome nastaju. "Lewis (2004) je definirao osobnu odgovornost kao učestalost kojom se učenici upuštaju u odgovorno ponašanje u razredu, što uključuje zaštitu prava učenika i nastavnika u vezi s učenjem i emocionalnom i fizičkom sigurnošću. Bilo je pokušaja da se osobna odgovornost opiše kao sposobnost pojedinca da preuzme odgovornost za svoje odluke i postupke, posljedice koje iz njih nastaju, kao i učinak koji oni imaju na druge ljude (Linley i Maltby, 2009). Postojeća raznolikost tih pojmova poticaj je provedbi daljnjih istraživanja.

U posljednje vrijeme postoji sve veće prihvaćanje Swanerova (2005) stava. On tvrdi da osobnu odgovornost treba promatrati kao višedimenzionalni konstrukt koji uključuje biheviorističku, kognitivnu, emocionalnu i moralnu komponentu. $U$ ovome se istraživanju koristio višedimenzionalni pojam osobne odgovornosti koji su iznijeli Mergler i Shield (2016), jer njihov pojam uključuje tri aspekta: osobnu odgovornost, emocionalnu kontrolu, kontrolu ponašanja i kognitivnu kontrolu (Mergler i Shield, 2016).

\section{Razlike u socijalnim vještinama i osobnoj odgovornosti s obzirom na spol}

Jedan od razloga zašto je ovo istraživanje potrebno jest taj da su postojeći podaci o razlikama u socijalnim vještinama i osobnoj odgovornosti s obzirom na spol u određenoj mjeri kontradiktorni. U nekim istraživanjima došlo se do spoznaja da su nastavnici i roditelji procijenili da je razina socijalnih vještina kod dječaka viša nego kod djevojčica (Nourani, 1998), iako druga istraživanja o socijalnim vještinama i osobnoj odgovornosti pokazuju da djevojčice uglavnom imaju višu razinu razvijenosti socijalnih vještina i osobne odgovornosti nego dječaci (Akelaitis, 2015; Christodoulides, Derri, Tsivitanidou i Kioumourtzoglou, 2012). Rezultati ovoga istraživanja pokazuju potrebu za daljnjim ispitivanjima. Nije jasno jesu li razlike 
u socijalnim vještinama i osobnoj odgovornosti s obzirom na spol prave razlike $\mathrm{u}$ razvoju spolova ili su samo rezultat subjektivne percepcije ocjenjivača (Zsolnai i Kasik, 2014). Možda škole i nastavnici stvaraju obrazovno okruženje u kojem se bolje potiče socijalno ponašanje djevojčica (DiPrete i Jennings, 2011).

Drugi razlog zbog kojeg smo odlučili ispitati razlike s obzirom na spol temelji se na prije provedenim istraživanjima prema kojima je spol među najvažnijim čimbenicima u razvoju socijalnih vještina (Abdi, 2010; DiPrete i Jennings, 2011).

\section{Pojam škola za mladež}

Alternativne škole ili škole za mladež jesu one koje su osmišljene za pružanje obrazovanja učenicima koji su već ispali iz sustava redovnog školovanja (Raywid, 1994). Škole za mladež organiziraju specijaliziranu nastavu za učenike koji su prekinuli obrazovanje u redovnim školama. Problemi u ponašanju, bježanje s nastave, slab akademski uspjeh, trudnoća i sudske presude samo su neki od razloga zbog kojih su učenici premješteni u školu za mladež (Munoz, 2004). Škola za mladež obično je dio srednjoškolskog programa koji se nudi učenicima srednjoškolske dobi (Dunning-Lozano, 2016). Učenici koji pohađaju takve škole obično imaju jako slab akademski uspjeh i nemaju dovoljno bodova kako bi mogli maturirati ili ići u istu školu s vršnjacima (Dunning-Lozano, 2016). Alternativne škole ili škole za mladež pružaju i obrazovanje za posebnu populaciju, poput učenika s posebnim interesima u učenju ili učenika s poteškoćama, učenika koji bi mogli napustiti školovanje, nasilnih učenika, učenika koji su osuđeni na sudu ili učenika koji su u institucijama za maloljetnike. Takve škole imaju za cilj rehabilitirati učenike koji su izašli iz redovnoga srednjoškolskog sustava i vratiti ih u redovne srednje škole, pomoći učenicima kojima nedostaju potrebni bodovi za nastavak školovanja da ih nadoknade ili olakšati učenicima proces stjecanja alternativnih obrazovnih kvalifikacija (Dunning-Lozano, 2016). Kritičari takvoga oblika obrazovanja kritiziraju škole za mladež i smatraju da su one „odlagalište“ ili „odvojeni trak za 'slabu klasu’ učenika“, pogotovo za ugrožene mlade ljude te da su mehanizam za stratifikaciju učenika s obzirom na njihov socioekonomski status (Muñoz, 2004).

Tema ispitivanja osobne odgovornosti i socijalnih vještina u školama za mladež temelji se na tvrdnji da je u stvari malo toga poznato o tome što se događa unutar zidova tih škola (Kelly, 1993). Neki istraživači (Muñoz, 2004; Wilhite i Bullock, 2012) naveli su da se alternativno obrazovanje, pogotovo ono koje se odnosi na ugroženu skupinu mladih, često temelji na nepotpunim istraživanjima. Zbog toga su u središtu ovoga istraživanja ne samo srednje škole nego i škole za mladež.

\section{Istraživanje}

Cilj ovoga istraživanja jest ispitati socijalne vještine i osobnu odgovornost kod učenika srednjih škola i škola za mladež. Ovo istraživanje je i nov doprinos postojećoj literaturi, jer su ostala istraživanja u tom području ispitivala samo socijalne vještine 
učenika srednjih škola (Sniras i Malinauskas, 2005; Malinauskas i Emeljanovas, 2013), socijalne vještine učenika alternativnih škola (škola za mladež) (Hovell, Blumberg, Liles i Powell, 2001; Wilhite i Bullock, 2012), osobnu odgovornost učenika srednjih škola (Wright, Li, Ding i Pickering, 2010) i osobnu odgovornost učenika alternativnih škola (Pickering, 2008), a mi smo ispitali socijalne vještine i osobnu odgovornost učenika i srednjih i alternativnih škola. U ovom su radu spojena dva područja istraživanja koja su zasebno privukla veliku pažnju, ali nisu bila zajedno analizirana: socijalne vještine i osobnu odgovornost. Ispitali smo višestruke aspekte osobne odgovornosti (osobnu odgovornost, emocionalnu kontrolu, kontrolu ponašanja i kognitivnu kontrolu) kako bismo došli do opsežne procjene osobne odgovornosti. Također smo analizirali socijalne vještine i osobnu odgovornost s obzirom na spol, jer je spol među najvažnijim komponentama razvoja socijalnih vještina (Abdi, 2010; DiPrete i Jennings, 2011; Ozben, 2013; Zsolnai i Kasik 2014).

Sljedeća pitanja istraživanja bila su smjernica u procesu provedbe istraživanja, koje se temelji na integraciji socijalnih vještina i osobne odgovornosti u kontekstu dviju različitih vrsta škola:

1. Razlikuju li se socijalne vještine i osobna odgovornost u srednjim školama i školama za mladež?

2. Postoje li razlike u socijalnim vještinama i stupnju osobne odgovornosti kod učenika srednjih škola i škola za mladež s obzirom na njihov spol?

Ispitali smo dvije hipoteze na temelju prije provedenih istraživanja:

(H1) Socijalne vještine i osobna odgovornost učenika srednjih škola znatno su veći nego kod učenika škola za mladež. Ta hipoteza temelji se na provedenom istraživanju (Cash, 2004) koje pokazuje da učenici škola za mladež imaju slabije razvijene socijalne vještine i osobnu odgovornost jer su škole za mladež koncipirane tako da pružaju specijaliziranu nastavu učenicima s problemima u ponašanju, učenicima koji bježe s nastave ili imaju slab akademski uspjeh.

(H2) Socijalne vještine i osobna odgovornost učenica znatno su veće nego učenika. Ta hipoteza zasnovana je na provedenome istraživanju u kojemu se došlo do spoznaja da učenice usvajaju socijalne vještine u ranijoj životnoj dobi od učenika, i zbog toga imaju bolje razvijene prosocijalne vještine (Bennett, Farrington i Huesmann, 2005). Hipoteza se temelji na rezultatima do kojih je došao Margetts (2005), a prema kojima djevojke imaju bolje socijalne vještine od svojih muških vršnjaka jer dječaci u toj dobi nailaze na veći broj problema u ponašanju i češće se služe fizičkim nasiljem.

\section{Metode \\ Sudionici}

Uzorak učenika odabran je nasumično. Za potrebe ovoga istraživanja odabrano je 420 sudionika iz različitih srednjih škola i škola za mladež u regiji Kaunas. Sudionicima nije ponuđen nikakav poticaj da bi sudjelovali u istraživanju. Učenici koji nisu dali 
potpune podatke isključeni su iz analize, što je dovelo do krajnjeg broja od 408 učenika koji su bili sudionici u istraživanju. Uzorak sudionika činila su 203 učenika i 205 učenica. 210 ih je pohađalo srednje škole, a 198 škole za mladež. Srednja dob učenika bila je 16,72 godine $(S D=0,96)$. Nije bilo razlike s obzirom na spol i dob kod učenika srednjih škola i učenika škola za mladež $(\mathrm{t}(406)=-1,53$, n.s.). Sudionici su ispunili upitnik tijekom redovne nastave, bez vremenskoga ograničenja. Istraživač je upoznao učenike $s$ istraživanjem i dao sudionicima informacije o ciljevima istraživanja prije nego im je podijelio upitnik. Samo istraživanje provedeno je u Litvi, a odobrio ga je Odbor za etiku u društvenim istraživanjima Litvanskog sportskog sveučilišta. Istraživanje je provedeno u skladu s etičkim smjernicama i pravnim kodeksom države $\mathrm{u}$ kojoj je provedeno. Upitnik je sadržavao instrumente navedene $\mathrm{u}$ daljnjem tekstu.

\section{Instrumenti}

Inventar socijalnih vještina. Inventar socijalnih vještina izradio je Riggio (1986). To je inventar Likertova tipa koji se sastoji od 90 tvrdnji s pomoću kojih ispitanici daju podatke o sebi. Sastoji se od šest podskala, a svaka sadrži 15 tvrdnji koje se označavaju vrijednostima od 1 (uopće nije ni slično meni) do 5 (ovo mi potpuno odgovara). Koristi se za izračunavanje razine ukupnih socijalnih vještina pojedinca. Viši rezultat upućuje na višu razinu socijalnih vještina. Riggio (1986) je dobio koeficijent pouzdanosti od 0,4 na testu i ponovnom testu, a konkurentna valjanost i diskriminantna valjanost variraju od 0,12 do 0,47 . Alfa koeficijent za cjelokupan rezultat bio je 0,67 za ovaj uzorak. Litvanska inačica Inventara socijalnih vještina pokazuje vrijednost unutarnje konzistencije od 0,82 i koeficijent pouzdanosti od 0,86 za cijeli upitnik (Malinauskas, 2004).

Skala osobne odgovornosti (Mergler i Shield, 2016). Skala se sastojala od 15 tvrdnji koje mjere aspekte osobne odgovornosti i uključivala je Likertovu skalu u rasponu od 1 (uopće se ne slažem) do 4 (u potpunosti se slažem). Tako je ukupan rezultat u rasponu od 15 do 60 , a visok rezultat upućuje na visoku razinu osobne odgovornosti. Skala osobne odgovornosti sastoji se od tvrdnji koje odražavaju tri aspekta osobne odgovornosti: osobnu odgovornost (spremnost pojedinca da preuzme odgovornost za svoj izbor), emocionalnu kontrolu, kontrolu ponašanja (obuhvaća različita ponašanja koja odražavaju (ne)sposobnost pojedinca da regulira nagle reakcije na društveno prihvatljive načine) i kognitivnu kontrolu (sposobnost pojedinca da regulira vlastite misli) (Mergler i Shield, 2016). Sudionici su trebali zaokružiti odgovor za koji im se čini da ih najbolje opisuje. Primjeri tvrdnji su: „Često nešto udarim kada sam jako uznemiren“ $i$ „Odabirem način na koji ću reagirati u određenim situacijama“. Pouzdanost je provjerena s pomoću Cronbachove alfe. Za tri podskale Cronbachova alfa iznosila je 0,81, 0,81 i 0,71 te se smatrala odgovarajućom (George i Mallery, 2014). U ovome istraživanju Cronbachova alfa iznosila je 0,65 za ukupan rezultat Skale osobne odgovornosti, što upućuje na prihvatljivu unutarnju pouzdanost. Vrijednosti Cronbachove alfe za podskale iznosile su 0,69, 0,67 i 0,61 te su također bile prihvatljive (George i Mallery, 2014). 
Obrazac o osobnim podacima. Sudionici su trebali dati podatke o sociodemografskim varijablama, kao što su spol, dob i vrsta škole koju pohađaju.

\section{Analiza podataka}

Izračunata je deskriptivna statistika, tj. izračunate su srednje vrijednosti, standardne devijacije i razlike u srednjim vrijednostima (Ds). Izračunati su koeficijenti asimetričnosti (simetrija distribucije) i zaobljenosti distribucije (homogenost distribucije) kako bi se procijenila univarijatna normalnost, jer MANOVA zahtijeva normalno distribuirane podatke (Gravetter i Wallnau, 2000). U praksi se smatra da koeficijenti asimetričnosti i zaobljenosti distribucije između +1 i -1 pokazuju da su podaci normalno distribuirani (Garson, 2012). Pearsonovi koeficijenti korelacije dobiveni su za sve kontinuirane varijable.

MANOVA se koristila za ispitivanje utjecaja vrste škole i spola na socijalne vještine i dimenzije osobne odgovornosti. Provedeni su preliminarni testovi kako bi se provjerila multikolinearnost, sferičnost i homogenost varijance. Rezultati nisu pokazali ozbiljnija neslaganja s pretpostavkama u MANOVA analizi. S pomoću Wilksove lambde procijenjeni su multivarijatni učinci, a razina značajnosti bila je 0,05 . Veličine učinka za F-statistiku bile su izražene kao parcijalni eta kvadrat $\left(\eta_{\mathrm{p}}{ }^{2}\right)$. Taj statistički podatak varira od 0 do 1 i predstavlja omjer varijance u zavisnoj varijabli, koja se objašnjava $s$ pomoću skupine nezavisnih varijabli. Tabachnick i Fidell (2007) smatraju da veličina učinka koja se temelji na $\eta p^{2}=, 01$ odgovara malom učinku, $\eta p^{2}=, 09$ odgovara srednje velikom učinku, a $\eta p^{2}=, 25$ prikazuje velik učinak. Sve statističke analize provedene su uz pomoć SPSS-a (verzija 24.0).

\section{Rezultati}

$\mathrm{U}$ ovome istraživanju pokušali smo odrediti razlike u socijalnim vještinama i osobnoj odgovornosti između učenika srednjih škola i učenika škola za mladež. Rezultati dobiveni u ovom istraživanju prikazani su u daljnjem tekstu. Tablica 1 prikazuje srednje vrijednosti, standardne devijacije, asimetričnost i zaobljenost distribucije, zatim standardne pogreške asimetričnosti i zaobljenosti distribucije za sve varijable. Kod svih su varijabli provjerene asimetričnost i zaobljenost distribucije i došlo se do zaključka da one imaju prihvatljivu distribuciju pa je bilo moguće provesti MANOVA analizu.

\section{Tablica 1}

Izračunati su Pearsonovi koeficijenti korelacije kako bi se ispitao uzorak korelacija između zavisnih varijabli i potvrdilo nepostojanje multikolinearnosti. MANOVA se smatra beskorisnom ako su zavisne varijable u visokoj pozitivnoj korelaciji ili uopće nisu u korelaciji (Tabachnick i Fidell, 2007). U Tablici 2 prikazane su korelacije između zavisnih varijabli zasebno za učenike srednjih škola i za učenike škola za mladež. Zavisne varijable koreliraju u pozitivnom smjeru. 
Tablica 2

Homogenost varijance dobivena je s pomoću Levenova testa i smatra se zadovoljavajućom (sve vrijednosti $\mathrm{p}>0,05$ ).

MANOVA se koristila kako bi se ispitalo u kolikoj mjeri vrsta škole i spol utječu na socijalne vještine i dimenzije osobne odgovornosti. Multivarijatne MANOVA analize pokazale su malen učinak vrste škole $(\mathrm{F}(4,401)=2,73, \mathrm{p}=, 029$; Wilk's $1=0,97$; $\left.\eta \mathrm{p}^{2}=, 03\right)$. Multivarijatni test pokazao je da spol također utječe na socijalne vještine i dimenzije osobne odgovornosti $\left(\mathrm{F}(4,401)=2,77, \mathrm{p}=, 027\right.$, Wilk's $\left.\mathrm{l}=, 97 ; \eta \mathrm{p}^{2}=, 03\right)$. Ukupni rezultati MANOVA analize nisu pokazali značajan učinak vrste škole u smislu interakcije s obzirom na spol $(\mathrm{F}(4,401)=1,76, \mathrm{p}=, 136$; Wilk's $\mathrm{l}=, 98)$.

Univarijatne MANOVA analize potvrdile su učinak vrste škole na tri zavisne varijable (Tablica 3$)$.

\section{Tablica 3}

Jednostavna analiza glavnih učinaka pokazala je da učenici srednjih škola imaju razvijenije socijalne vještine $(\mathrm{D}=4,75, \mathrm{p}=, 010)$, emocionalnu kontrolu i kontrolu ponašanja $(\mathrm{D}=, 56, \mathrm{p}=, 006)$ i ukupan rezultat osobne odgovornosti $(\mathrm{D}=1,04, \mathrm{p}=$ ,004). Univarijatna analiza koja je nakon toga uslijedila pokazala je malen utjecaj ( $\eta \mathrm{p}^{2}$ $=, 02)$ spola na socijalne vještine $(\mathrm{D}=4,78, \mathrm{p}=, 010)$ : djevojke su imale višu razinu socijalnih vještina. Univarijatne analize za spol pokazale su utjecaj na sljedeće zavisne varijable: osobnu odgovornost $\left(\mathrm{F}(1,404)=4,25 ; \mathrm{p}=, 040, \eta \mathrm{p}^{2}=, 01\right)$, emocionalnu kontrolu i kontrolu ponašanja $\left(\mathrm{F}(1,404)=5,39 ; \mathrm{p}=, 021, \eta \mathrm{p}^{2}=, 01\right)$ i ukupnu osobnu odgovornost $\left(\mathrm{F}(1,404)=10,93 ; \mathrm{p}=.001, \eta \mathrm{p}^{2}=, 03\right)$. Osobna odgovornost $\mathrm{i}$ emocionalna kontrola i kontrola ponašanja bolje su razvijene kod učenica nego kod učenika.

\section{Rasprava}

Cilj je ovoga istraživanja bio ispitati socijalne vještine i osobnu odgovornost kod učenika srednjih škola i učenika škola za mladež. $U$ ovome su istraživanju ispitane razlike u socijalnim vještinama i osobnoj odgovornosti, kao i razlike između učenika s obzirom na spol. Nismo pronašli značajan utjecaj vrste škole u interakciji među spolovima na socijalne vještine i osobnu odgovornost, ali je istraživanje pokazalo da postoje razlike u socijalnim vještinama i osobnoj odgovornosti između učenika srednjih škola i učenika škola za mladež, kao i učenika i učenica. Multivarijatni test pokazao je da vrsta škole i spol utječu na socijalne vještine i osobnu odgovornost (mali glavni učinak $\eta p^{2}=, 03$ u oba slučaja).

Potvrđena je naša prva hipoteza da su socijalne vještine i osobna odgovornost učenika srednjih škola znatno razvijeniji nego kod učenika škola za mladež. Ovo je istraživanje pokazalo da su socijalne vještine učenika srednjih škola na višoj razini nego kod učenika škola za mladež (veličina učinka bila je slaba, $\eta p^{2}=, 02$ ), što je u skladu s rezultatima koje su dobili Malinauskas i sur. (2014), gdje su učenici srednjih škola 
imali bolje razvijene socijalne vještine; prihvaćanje drugih, emocionalna udobnost i otvorenost među učenicima srednjih škola bili su izraženiji nego kod učenika škola za mladež (veličina učinka bila je slaba i varirala je od vrijednosti Cohenova $\mathrm{d}=$ $-0,18$ do $d=-0,24)$. Niža razina socijalnih vještina učenika škola za mladež može se objasniti njihovim osobinama, jer škole za mladež organiziraju nastavu za učenike $s$ problemima u ponašanju, učenike koji bježe s nastave i imaju slab akademski uspjeh. $\mathrm{K}$ tomu, razina socijalnih vještina može se povećati boljim nastavnim uvjetima, $\mathrm{u}$ kojima učenici imaju priliku komunicirati i surađivati. Neka istraživanja (npr. Cash, 2004) pokazala su da su alternativne škole/škole za mladež uspješne u suzbijanju bježanja s nastave, poboljšanja stavova prema školi i reduciranju problema u ponašanju.

Ovo je istraživanje također pokazalo da su osobna odgovornost i emocionalna kontrola (aspekt osobne odgovornosti) i kontrola ponašanja učenika srednjih škola razvijeniji nego kod učenika škola za mladež. Veličina učinka za promatrane razlike bila je mala $\left(\eta p^{2}=, 02\right)$. Naši rezultati o promatranim razlikama idu u prilog tvrdnji Arona i Zweiga (2003) da učenici škola za mladež nemaju kontrolu ponašanja. Rezultati ovoga istraživanja također su u skladu i s rezultatima još jednoga istraživanja u kojemu se došlo do spoznaje da učenici škola za mladež imaju višu razinu disruptivnog verbalnog ponašanja (Kleiner, Porch, i Farris, 2002). Rezultati također odgovaraju i istraživanju koje je pokazalo da su niska razina kontrole ponašanja i emocija, nemogućnost obuzdavanja ljutnje i zloporaba droga važni faktori koji se povezuju s ponašanjem u školi, što reflektira slabu sposobnost učenika da se odgovorno ponašaju i kontroliraju svoje postupke dok se nalaze u prostoru alternativne škole/škole za mladež (Herndon i Bembenutty, 2014). Činjenica da učenici škola za mladež imaju nižu razinu kontrole ponašanja i emocionalne kontrole, u skladu je s pojmom osobne odgovornosti koji su objasnili Mergler i Shield (2016). Oni su istaknuli važnost emocionalne kontrole i kontrole ponašanja kao dimenzije osobne odgovornosti.

Naši rezultati potvrđuju hipotezu 2 - da su kod učenica socijalne vještine i osobna odgovornost znatno bolje razvijeni nego kod učenika (veličina učinka bila je mala, $\left.\eta \mathrm{p}^{2}=, 03\right)$. Univarijatna analiza pokazala je malen utjecaj $\left(\eta_{\mathrm{p}}{ }^{2}=, 02\right)$ spola na socijalne vještine učenika. Taj rezultat sličan je rezultatima prethodno provedenih istraživanja (Margalit i Eysenck, 1990; Zsolnai i Kasik, 2014), u kojima su djevojke pokazale višu razinu socijalnih vještina nego mladići; veličina učinka bila je mala $\left(\eta_{\mathrm{p}}{ }^{2}=, 03\right)$. Rezultati našega istraživanja mogli bi se objasniti s pomoću rezultata Bennetta i sur. (2005), koji su pokazali da djevojke u ranijoj životnoj dobi usvajaju socijalne vještine nego mladići pa da zbog toga imaju bolje prosocijalne vještine. Mladići razvijaju sposobnost samokontrole kasnije od djevojaka pa često ne mogu kontrolirati svoje emocije, brzo se razljute, ne pokazuju poštovanje ni toleranciju prema drugim ljudima i često ne razumiju svoje osjećaje ni osjećaje drugih ljudi (Bennett i sur., 2005). Na superiornije socijalne vještine djevojaka mogu utjecati i mnogi drugi čimbenici, poput veće verbalne sposobnosti i različite socijalizacije i interakcije s roditeljima i vršnjacima (Bennett i sur., 2005; Ozben, 2013). 
Univarijatna analiza pokazala je da spol utječe na osobnu odgovornost, malen utjecaj spola na ukupan rezultat o osobnoj odgovornosti $\left(\eta_{\mathrm{p}}{ }^{2}=, 03\right)$ i na njezine druge aspekte: osobnu odgovornost $\left(\eta \mathrm{p}^{2}=, 01\right)$ i emocionalnu kontrolu i kontrolu ponašanja $\left(\eta_{\mathrm{p}}{ }^{2}=, 01\right)$. Taj rezultat povezan sa spolom u skladu je s rezultatima drugih istraživanja koje su proveli Carbonero, Martín-Antón, Monsalvo i Valdivieso (2015), a u kojima je uočena niska veličina učinka za jedan od aspekata osobne i socijalne odgovornosti (Cohenov $d=0,26)$. Moguće objašnjenje više razine osobne odgovornosti kod djevojaka moglo bi biti da obje vrste škola (i srednje škole i škole za mladež) mogu stvoriti obrazovno okruženje u kojem se može razviti osobna odgovornost i socijalno ponašanje djevojaka (DiPrete i Jennings 2011). Na primjer, Entwisle, Alexander i Olson (2007) tvrdili su da djevojke imaju bolje rezultate u socijalnim vještinama i ponašanju ne toliko zbog razlika u zrelosti, već zbog toga što se „one bolje osjećaju u ulozi učenika nego mladići“ (str. 134), tj. imaju višu razinu osobne odgovornosti i veću emocionalnu kontrolu i kontrolu ponašanja.

\section{Ograničenja i buduća istraživanja}

Jaka strana ovoga istraživanja jest relativno velik uzorak. Međutim, ono ima neka ograničenja. Ovo je istraživanje više presječno nego eksperimentalno, a korelacijska priroda nacrta istraživanja otežava zaključak o uzročno-posljedičnim vezama, tj. da vrsta škole i spol utječu na socijalne vještine i osobnu odgovornost. Drugo je njegovo ograničenje to što smo se oslanjali na jednostruko mjerenje socijalnih vještina. Iako se Inventar socijalnih vještina najčešće koristi za mjerenje socijalnih vještina, postoje i drugi načini koji su možda mogli dati detaljniju procjenu (na primjer, Skala o školskom socijalnom ponašanju, koja se koristi za procjenu socijalnih vještina i antisocijalnoga ponašanja u okruženju). Varijable koje su važne u ovome istraživanju bile su ograničene na spol, vrstu škole, socijalne vještine i osobnu odgovornost. Buduća bi istraživanja mogla proširiti naš nacrt istraživanja i ispitati različite psihosocijalne varijable, kao što su samopoštovanje, samoučinkovitost i blagostanje.

\section{Zaključak}

Multivarijatna analiza pokazala je glavni utjecaj vrste škole i spola na socijalne vještine i osobnu odgovornost kod učenika. Univarijatna analiza pokazala je da su socijalne vještine učenika i njihova osobna odgovornost bolje razvijeni u srednjim školama nego u školama za mladež te da su razvijeniji kod ženskog nego kod muškog spola. 